Вісник Дніпропетровського університету. Біологія. Медицина. - 2010. - Вип. 1, т. 2. - С. 3-7.

Visnyk of Dnipropetrovsk University. Biology. Medicine. - 2010. - Vol. 1, N 2. - P. 3-7.

УДК 579.87:631.46

\author{
А. Р. Абушова, С. А. Гасанова, М. А. Касимзаде \\ Бакинский государственный университет, Азербайджан

\section{ЭКОЛОГИЧЕСКИЕ ОСОБЕННОСТИ РЕДКИХ РОДОВ АКТИНОМИЦЕТОВ В ПОЧВАХ АЗЕРБАЙДЖАНА}

Исследованы редкие роды актиномицетов в некоторых почвах Азербайджана. На селективных средах выявляются представители родов Streptomyces, Streptosporangium, Micromonospora, Actinomadura, Microbispora, Saccharopolyspora и Saccharomonospora. Представители родов Streptomyces и Micromonospora доминируют в горно-лесных экосистемах $(60 \%)$. Среди стрептомицетов встречаются виды секции Cinereus серии Violaceus, секции Helvolo-Flavus серии Helvolus, секции Roseus серии Fuscus, секции Azureus серии Coerulescens. Численность термотолерантных актиномицетов в исследованных пустынных почвах Азербайджана зависит от температуры инкубации. Из пустынных почв Азербайджана выделены термотолерантные представители родов Streptomyces, Micromonospora, Saccharopolyspora и Actinomadura.
А. Р. Абушова, С. А. Гасанова, М. А. Касимзаде
Бакинський державний університет, Азербайджан

\title{
ЕКОЛОГІЧНІ ОСОБЛИВОСТІ РІДКІСНИХ РОДІВ АКТИНОМІЦЕТІВ У ГРУНТАХ АЗЕРБАЙДЖАНУ
}

Досліджено рідкісні роди актиноміцетів у деяких грунтах Азербайджану. На селективних середовищах виявляються представники родів Streptomyces, Streptosporangium, Micromonospora, Actinomadura, Microbispora, Saccharopolyspora та Saccharomonospora. Представники родів Streptomyces i Micromonospora домінують у гірсько-лісових екосистемах $(60$ \%). Серед стрептоміцетів трапляються види секції Cinereus cерії Violaceus, секції Helvolo-Flavus серії Helvolus, секції Roseus cepiї Fuscus, секції Azureus cepiї Coerulescens. Чисельність термотолерантних актиноміцетів у досліджених пустельних грунтах Азербайджану залежить від температури інкубації. Із пустельних грунтів Азербайджану виділені термотолерантні представники родів Streptomyces, Micromonospora, Saccharopolyspora та Actinomadura.

\author{
A. R. Abushova, S. A. Gasanova, M. A. Kasimzade \\ Baku State University, Azerbaijan
}

\section{ECOLOGICAL FEATURES OF RARE ACTINOMYCETES GENERA IN SOILS OF AZERBAIJAN}

The results of the research of rare species of actinomycetes in some soils of Azerbaijan were studied. On the selective media the representatives of Streptomyces, Streptosporangium, Micromonospora, Actinomadura, Microbispora, Saccharopolyspora and Saccharomonospora were revealed. Species of Streptomyces and Micromonospora dominate in mountain- wood ecosystems (60 \%.). It was established that among streptomyces species of Cinereus section of Violaceus series; Helvolo-Flavus sections of Helvolus series, Roseus sections of Fuscus series; Azureus sections of Coerulescens series. It was established that amount of termotolerant actinomycetes in the investigated desert soils of Azerbaijan depends on the incubation temperature. The species of Streptomyces, Micromonospora, Saccharopolyspora and Actinomadura genera were isolated from desert soils of Azerbaijan. 


\section{Введение}

Азербайджан является развивающейся промышленной страной, для которой сельскохозяйственное производство имеет большое значение. Для дальнейшего развития и интенсификации сельскохозяйственного производства необходимо углубленное изучение свойств почв и их микробиологической активности как фактора почвообразования и плодородия почв. Микроорганизмы ответственны за многие экологические функции почв [7; 12]. В настоящее время почва рассматривается «как банк, в котором хранятся самые разнообразные виды микроорганизмов, или как генофонд микромира», и соответственно подобному взгляду на почву разрабатываются теоретические основы и методические подходы к оценке природных ресурсов микроорганизмов в почвах и растительных субстратах [5].

Актиномицеты представляют собой единое звено в трофической цепи экосистемы, осуществляя функции редуцентов. Основная роль мицелиальных прокариот состоит в разложении сложных полимеров (лигнин, хитин, ксилан, целлюлоза, гумусовые соединения) $[13 ; 14 ; 17 ; 18]$. Отдельные представители родов Nocardia, Micromonospora способны окислять гуматы, принимая участие в минерализации гумусовых веществ в почве [10]. Увеличение численности почвенных актиномицетов происходит на поздних этапах микробной сукцессии, когда биомасса грибов начинает снижаться [9].

Микробиологические исследования почв в Азербайджане начаты в 1960-х годах Г. С. Касимовой с сотрудниками на кафедре микробиологии $[1 ; 8]$. Основное внимание таксономических исследований при этом было уделено из актиномицетов только роду Streptomyces.

С 1994 г. начато изучение редких родов почвенных актиномицетов Азербайджана. Однако до настоящего времени не ясна роль редких родов актиномицетов в почвообразовании, плодородии и сукцессиях микроорганизмов в разных типах почв и экосистем, что определяет актуальность и практическую значимость проводимых исследований. Представляет несомненный интерес исследование биологии и экологии актиномицетов, в частности, их редких форм в почвах Азербайджана.

\section{Материал и методы исследований}

Исследовали основные типы почв Азербайджана. Методика исследования включала проведение полевых изысканий, постановку модельных опытов, проведение лабораторных анализов. Для наиболее полного выделения редко встречающихся форм актиномицетов из почвы использован комбинированный метод (селективные среды с пропионатом натрия [4], гумус - витаминный агар [15], КАА, казеин-глицериновый агар и Гаузе-1 [3], состоящий из селективных приемов, направленных на подавление роста немицелиальных бактерий, грибов и стимуляцию роста представителей редких родов актиномицетов. Почвенные образцы перед посевом прогревали при $+120{ }^{\circ} \mathrm{C}$ в течение 1 часа (для селективной среды).

Идентификацию выделенных штаммов проводили согласно определителю Гаузе [3], Берджи [11] и руководству «The Prokaryotes» [15], используя морфологические показатели, а также хемотаксономические признаки: присутствие в гидролизатах целых клеток $L L$ - или мезо-ДАПк (диаминопимелиновые кислоты) и диагностических сахаров в гидролизатах целых клеток. Меланоидные пигменты определяли на среде с тирозином и пептонно-дрожжевым экстрактом [6]. 


\section{Результаты и их обсуждение}

На селективных средах выявляются представители рода Streptomyces - во всех экосистемах, Streptosporangium и Micromonospora - чаще в горно-лесных экосистемах, Actinomadura и Microbispora - чаще в степных, Saccharopolyspora и Saccharomonospora во всех, кроме горно-лесных экосистем, Microtetraspora и Dactylosporangium - в полупустынных экосистемах (рис. 1). Во всех экосистемах в комплексе доминируют стрептомицеты. Представители рода Streptomyces и Micromonospora доминируют в горнолесных экосистемах (60\%).

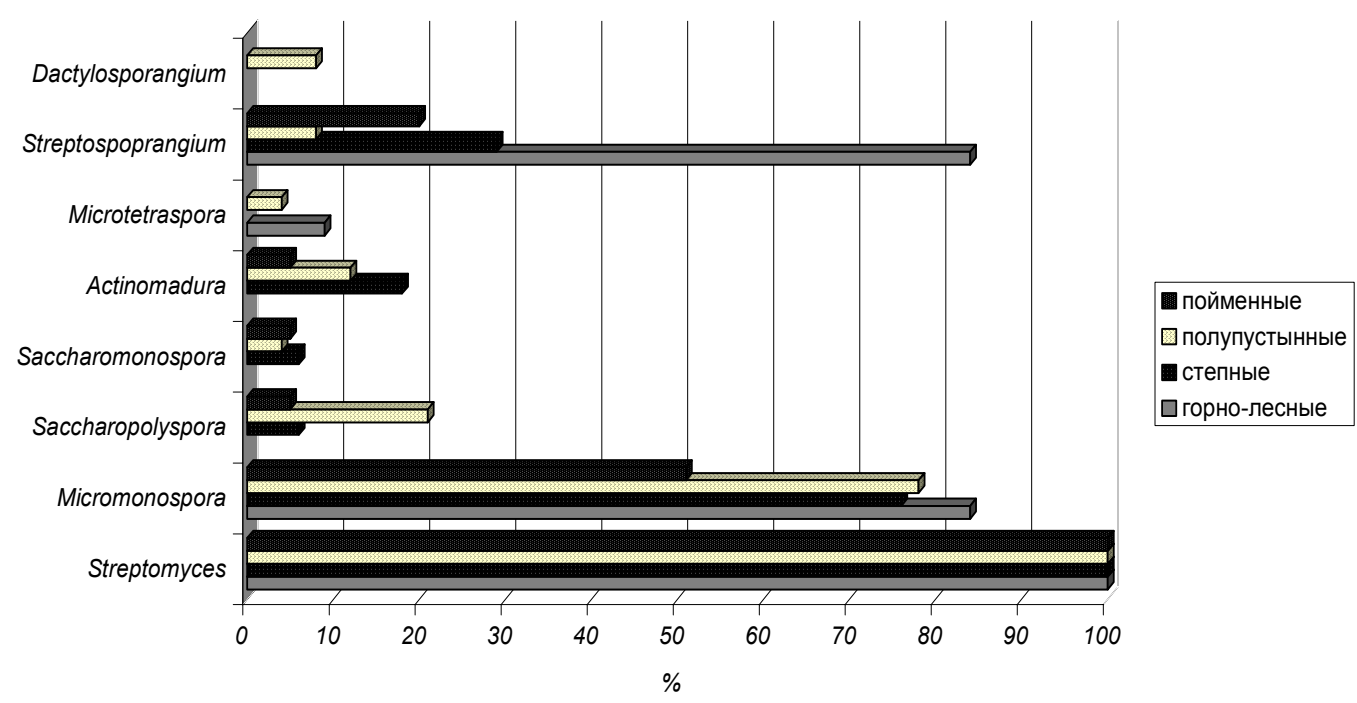

Рис. 1. Частота встречаемости отдельных родов актиномицетов в разных экосистемах на среде с пропионатом натрия

Среди стрептомицетов встречаются виды секции Cinereus cepии Violaceus в горно-лесных и степных экосистемах, секции Helvolo-Flavus серии Flavus и секции Roseus серии Fuscus - только в полупустынных, секции Azureus серии Coerulescens - в пойменных экосистемах Азербайджана.

Активность термотолерантных актиномицетов в почве связывают с синтезом и разложением гумусовых веществ, продукцией антибиотических веществ и азотным балансом почвы. Некоторые их представители являются активными утилизаторами целлюлозы в процессе компостирования городских отходов. В настоящее время термофильные актиномицеты активно изучаются как продуценты различных ферментов, в том числе синтезирующих комплекс протеолитических ферментов. Большинство термофильных актиномицетов растут быстрее актиномицетов мезофильных, имеют более термоустойчивые споры и низкий антагонистический потенциал [2].

Численность термотолерантных актиномицетов в исследованных пустынных почвах Азербайджана колеблется от сотен до десятков тысяч колониеобразующих единиц (КОЕ) в 1 г почвы в зависимости от ее типа. Границы общей численности мезофильных актиномицетов не выходят за указанные пределы (сотни - десятки тысяч КОЕ/Г), однако представители разных родов ведут себя по-разному при определенных температурах выделения. Из пустынных почв Азербайджана выделены (при инкубировании посевов при $+35,+37$ и $+45{ }^{\circ} \mathrm{C}$ ) термотолерантные представители родов Streptomyces, Micromonospora, Saccharopolyspora и Actinomadura (рис. 2). 


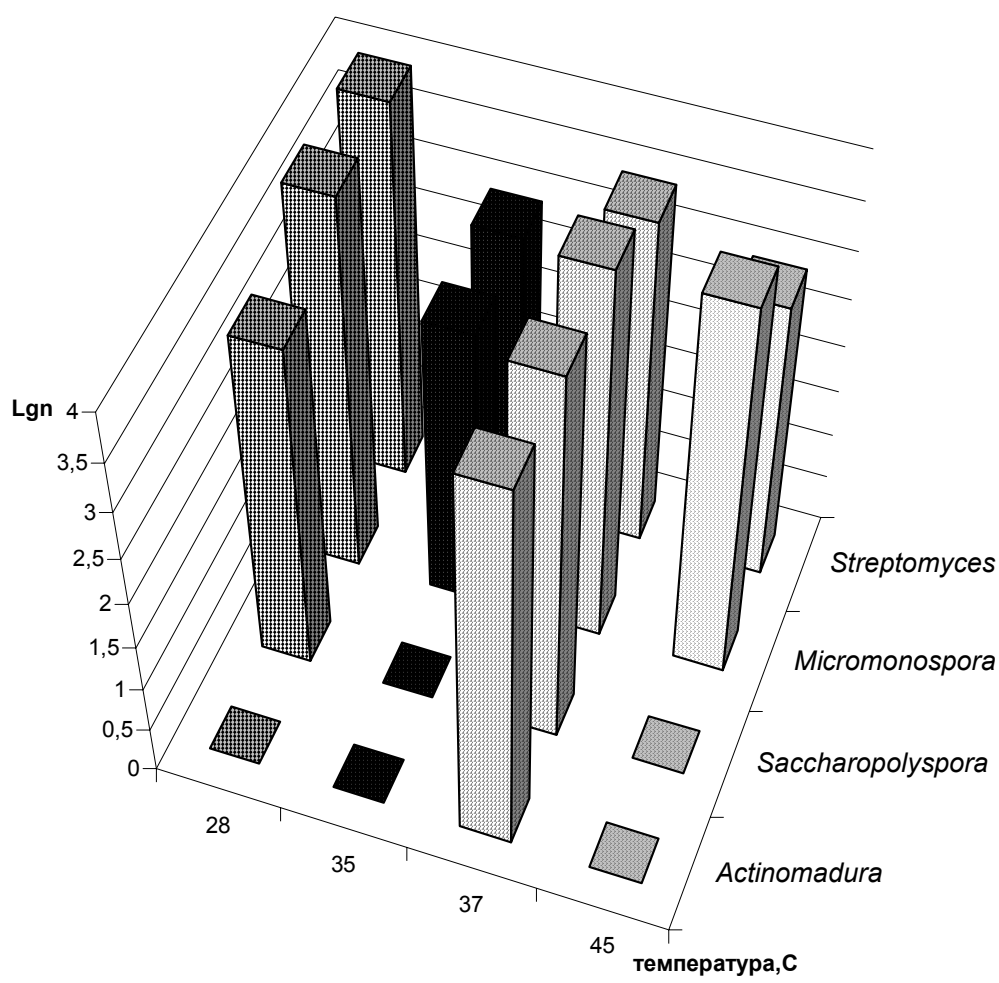

Рис. 2. Численность актиномицетов отдельных родов в бурой полупустынной почве при разных температурах инкубации посевов

\section{Выводы}

Во всех экосистемах в комплексе доминируют стрептомицеты. Представители рода Streptomyces и Micromonospora доминируют в горно-лесных экосистемах (60\%). Численность термотолерантных актиномицетов в исследованных почвах Азербайджана колеблется от сотен до десятков тысяч колониеобразующих единиц в 1 г в зависимости от типа почвы.

\section{Библиографические ссылки}

1. Абушов Р. А. Физиолого-биохимические свойства актиномицетов Азербайджана и их народнохозяйственное значение: Автореф. дисс. ... д-ра биол. наук. - Баку, 2004. - 54 с.

2. Агре Н. С. Систематика термофильных актиномицетов. - Пущино, 1986. - 130 с.

3. Определитель актиномицетов / Г. Ф. Гаузе, Т. П. Преображенская, М. А. Свешникова и др. М. : Наука, 1983. -248 c.

4. Добровольская Т. Г. Методы выделения и идентификации почвенных бактерий / Т. Г. Добровольская, И. Н. Скворцова, Л. В. Лысак. - М. : Изд-во МГУ, 1989. - 72 с.

5. Звягинцев Д. Г. Экология актиномицетов / Д. Г. Звягинцев, Г. М. Зенова. - М. : ГЕОС, 2001. $-253 \mathrm{c}$.

6. Зенова Г. М. Почвенные актиномицеты редких родов. - М. : Изд-во МГУ, 2000. - 81 с.

7. Карпачевский Л. О. Экологические почвоведение. - М. : Изд-во МГУ, 1994.

8. Касимова Г. С. Актиномицеты почв Кура-Араксинской низменности // Ученые записки АГУ. Баку, 1973. - Сер. биол., № 2. - С. 26-29.

9. Полянская Л. М. Микробная сукцессия в почве Автореф. дис. ... д-ра биол. наук. - М. : МГУ, 1996. $-96 \mathrm{c}$.

10. Теппер Е. И. Микроорганизмы рода Nocardia и разложение гумуса. - М. : Наука, 1976. - 199 с. 
11. Bergey's manual determinative bacteriology / Eds. J. A. Holt et al. - Baltimore : Williams and Wilkins, 1994. $-787 \mathrm{p}$.

12. Actinomycetes isolated from lichens: Evaluation of their diversity and detection of biosynthetic gene sequences / I. Gonzalez, A. Ayuso-Sacido, A. Anderson, O. Genilloud // FEMS Microbiol. Ecology. 2005. - Vol. 54, N 3. - P. 401-415.

13. Microbial cellulose utilization: Fundamentals and biotechnology / L. R. Lynd, P. J. Weimer, W. H. Van Zyl, I. S. Pretorius // Microb. Mol. Biol. Rev. - 2002. - Vol. 66. - P. 506-577.

14. Mc Carthy A. J. Methods for studying the ecology of actinomycetes / A. J. Mc Carthy, S. T. Williams // Methods in Microbiology. - 1990. - Vol. 29. - P. 563-583.

15. Nonomura H. New methods for selective isolation of soil actinomycetes / H. Nonomura, M. Hayakawa // Y. Okami, T. Beppu, H. Ogawara (Eds.) Biology of Actinomycetes. - Tokyo : Japan Sci. Sec. Press, 1988. - P. 288-293.

16. The Prokaryotes. A handbook on habitats, isolation and identification of bacteria / Eds. M. P. Starr et al. - Berlin, Heidelberg, New York: Springer-Verlag, 1991. - Vol. 2. - P. 1913-2125.

17. Trigo C. Is the solubized product from the degradation of ligno-cellulose by actinomycetes as precursor of humic substances? / C. Trigo, A. S. Ball // Microbiology. - 1994. - Vol. 140. - P. 3145-3152.

18. Williamson N. Molecular detection of bacterial and streptomycete chitinases in the enviroment / N. Williamson, P. Brian, E. M. H. Wellington // Antonie van Leeuwenhoek. -2000. -Vol. 78. - P. 315-321.

Надійшла до редколегії 14.01.2010 